\section{Distinction of Ozothamnus diosmifolius (Vent.) DC Genotypes Using RAPD}

\author{
H.L. Ko and R.J. Henry \\ Department of Primary Industries, Queensland Agricultural Biotechnology \\ Centre, Gehrmann Laboratories, The University of Queensland, Queensland \\ 4072, Australia
}

\author{
P.R. Beal, J.A. Moisander, and K.A. Fisher \\ Department of Primary Industries, Redlands Research Station, P.O. Box 327, \\ Cleveland, Queensland 4163, Australia
}

Additional index words. riceflower, genotype, selection

\begin{abstract}
An assessment was made to determine the suitability of RAPD analysis for identification of the Australian wildflower Ozothamnus diosmifolius (Vent.) DC [syn. Helichrysum diosmifolium (Vent.) Sweet] cultivars and lines. Of 19 arbitrary primer sequences tested, 16 revealed a high degree of polymorphism between the six most important genotypes with commercial significance, producing a total of 166 markers, of which $70 \%$ were polymorphic. Several primers (such as OPD-03 and OPM-07) were able to distinguish all tested genotypes from one another, showing an intracultivar consistency. These results indicate that RAPD analysis is a useful tool for establishing genetic diversity in this species as well as assisting in commercial protection of plant breeders' rights.
\end{abstract}

Riceflower is a native Australian wildflower (Fig. 1). It has been grown commercially in Australia since 1987 and marketed as a cut flower (a filler); most of it is destined for the overseas export market. This species has been introduced to intensive commercial horticulture by selection of wild seedlings for vegetative propagation. The best clonal lines were identified after comparative evaluations over 3 or more years in field or laboratory trials, then further propagated for commercial cut flower production. Selection within the species has been successful in isolating forms that differ in flower color (white and a range of pinks) and flowering season (Beal, 1994; Lacey, S., personal communication). Vegetative characteristics of this woody shrub species are difficult to distinguish with confidence. It is only at the flowering stage that the diverse flower shades become evident. Other properties, such as early flowering, cannot be detected morphologically. The short flowering period, 2 to 5 days of commercial acceptability for most cultivars, requires the use of many cultivars to achieve continuity of supply. With plant variety rights (PVR) being sought by growers, an early method of characterization and identification of various genotypes is essential.

Polymerase chain reaction [PCR (Saiki et al., 1988)] analysis using arbitrary oligonucleotide primers in random amplified polymorphic DNA [RAPD (Williams et al., 1990)] and other systems (e.g., microsatellites and ge-

Received for publication 16Feb. 1995. Accepted for publication 22 Mar. 1996. This study was undertaken with funding assistance from G. and E. Cook of Helidon and the Rural Industries Research and Development Corp. The cost of publishing this paper was defrayed in part by the payment of page charges. Under postal regulations, this paper therefore must be hereby marked advertisement solely to indicate this fact. Cook's Pom Pom Shrub to $1.5 \mathrm{~m}$ height, bushy, spread from base before growing upright and straight, dark blue-green rounded, medium-green leaves.

QDPI line 40b3

Tall shrub to $2.5 \mathrm{~m}$ height, with upright growth, medium-green leaves.

QDPI line 54.4 Small rounded shrub, 1-1.5 m height, closely branched mediumgreen leaves.
${ }^{\mathrm{z} F r o m ~ C o o k ~ a n d ~ L a w ~(1993) . ~}$
In our study, RAPD analysis was undertaken on six of the currently most important $O$. diosmifolius cultivars and lines, of which two are commercialized and protected by PVR. The usefulness of this identification method for this species was explored and established.

\section{Materials and Methods}

Plant material. All plant material originated in Australia. Two commercial cultivars ('Cook's Tall Pink' and 'Cook's Snow White') and two lines under development ('Cook's Salmon' and 'Cook's Pom Pom') were provided for testing by Graham and Esther Cook of Helidon, Queensland, who pioneered commercial riceflower growing (personal communication). Two lines (40b3 and 54.4), developed by the Queensland Department of Primary Industries' (QDPI) Redlands Research Station in Cleveland, Australia, were also included. Selected vegetative and floral characteristics of these lines are listed in Table 1. These lines, all identified as $O$. diosmifolius, were originally collected from diverse wild populations in eastern parts of Queensland and New South Wales.

DNA extraction. DNA for PCR was extracted from the youngest leaves according to Graham et al. (1994). Concentrations of the genomic DNA were determined spectrophotometrically and the quality of the extracted DNA was assessed on $0.7 \%(\mathrm{w} / \mathrm{v})$ agarose gels.

$P C R$. PCR conditions were optimized by titrating the concentrations of $\mathrm{MgCl}_{2}, \mathrm{Taq}$ DNA polymerase, and template to give the optimum resolution of amplification products.

Table 1. Description of Ozothamnus diosmifolius cultivars and lines included in the experiments.

\begin{tabular}{|c|c|c|}
\hline \multirow[b]{2}{*}{ Line/cultivar } & \multicolumn{2}{|c|}{ Characteristics } \\
\hline & Vegetative & Floral \\
\hline$\overline{\text { Cook's Salmon }}^{z}$ & $\begin{array}{l}\text { Tall shrub to } 2 \text { m height, bushy, } \\
\text { rounded shape, branches straight, } \\
\text { medium-green leaves. }\end{array}$ & $\begin{array}{l}\text { Domed corymbs, closely packed, } \\
\text { round to oval, medium-sized salmon } \\
\text { to pink buds with white tips, some } \\
\text { uneven flowering, main flush in } \\
\text { spring. }\end{array}$ \\
\hline Cook's Tall Pink ${ }^{2}$ & $\begin{array}{l}\text { Tall shrub }>2.5 \mathrm{~m} \text { height, upright, } \\
\text { open, inverted cone shape, mature } \\
\text { bush has many long, very thin } \\
\text { straight branches, dark green leaves. }\end{array}$ & $\begin{array}{l}\text { Loose, flat-topped corymbs, oval to } \\
\text { pointed, large dark pink buds with } \\
\text { white base, isolated early flowers, } \\
\text { main flush in spring. }\end{array}$ \\
\hline Cook's Snow White ${ }^{z}$ & $\begin{array}{l}\text { Tall shrub }>2.5 \mathrm{~m} \text { height, bushy, } \\
\text { young plants have circle of light, } \\
\text { secondary growth at base, branches }\end{array}$ & $\begin{array}{l}\text { Flat-topped corymbs, round and } \\
\text { very small white buds, flowering } \\
\text { in spring. }\end{array}$ \\
\hline
\end{tabular}

Highly domed corymbs closely packed, large, round to oval pink buds with white base, earliest $(\approx 1$ week earlier than Cook's Tall Pink) flowering line currently identified.

Domed corymbs, large, oval to pointed pink buds with white base, latest (late spring, $\approx 2-3$ weeks later than Cook's Tall Pink) flowering line currently identified.

Domed corymbs, small, round white buds, flowering $\approx 2$ weeks later than Cook's Tall Pink. 
Standard PCR conditions were then established using a $0.025-\mathrm{ml}$ reaction volume containing 30 ng of DNA; 1 unit of Taq DNA polymerase (Boehringer Mannheim Biochemica, Mannheim, Germany); $0.24 \mathrm{~mm}$ each of dATP (2'-deoxyadenosine $5^{\prime}$-triphosphate), dCTP (2'-deoxycytidine 5'-triphosphate), dGTP (2'-deoxyguanosine 5'-triphosphate), and dTTP (2'-deoxythymidine $5^{\prime}$-triphosphate) (Promega Corp., Madison, Wis.);
0.2 mm of 10 -mer oligonucleotide primer (Operon Technologies, Alameda, Calif.); and PCR buffer to give final concentrations of $10 \mathrm{~mm}$ Tris- $\mathrm{HCl}, 3 \mathrm{~mm} \mathrm{MgCl}_{2}, 50 \mathrm{~mm} \mathrm{KCl}$, gelatin at $0.1 \mathrm{mg} \cdot \mathrm{ml}^{-1}, \mathrm{pH} 8.3$. The commercially available decamer oligonucleotides used in this study are listed in Table 2. PCR reactions were repeated three to six times to confirm reproducibility of results.

A Perkin Elmer (Norwalk, Conn.) 9600
geneAmp PCR system was programmed for an initial denaturation cycle at $94^{\circ} \mathrm{C}$, followed by $30 \mathrm{~s}$ at $36^{\circ} \mathrm{C}, 1 \mathrm{~min}$ at $72{ }^{\circ} \mathrm{C}$, and $20 \mathrm{~s}$ at 94 ${ }^{\circ} \mathrm{C}$ for 10 cycles and finally $30 \mathrm{~s}$ at $37^{\circ} \mathrm{C}, 1 \mathrm{~min}$ at $72{ }^{\circ} \mathrm{C}$, and $15 \mathrm{~s}$ at $94^{\circ} \mathrm{C}$ for 30 cycles. PCR products were analyzed by electrophoresis in $1.5 \%(w / v)$ agarose gels. A marker was considered polymorphic when it was present in one or more cultivar(s) or line(s), but absent in at least one other tested cultivar or line, which
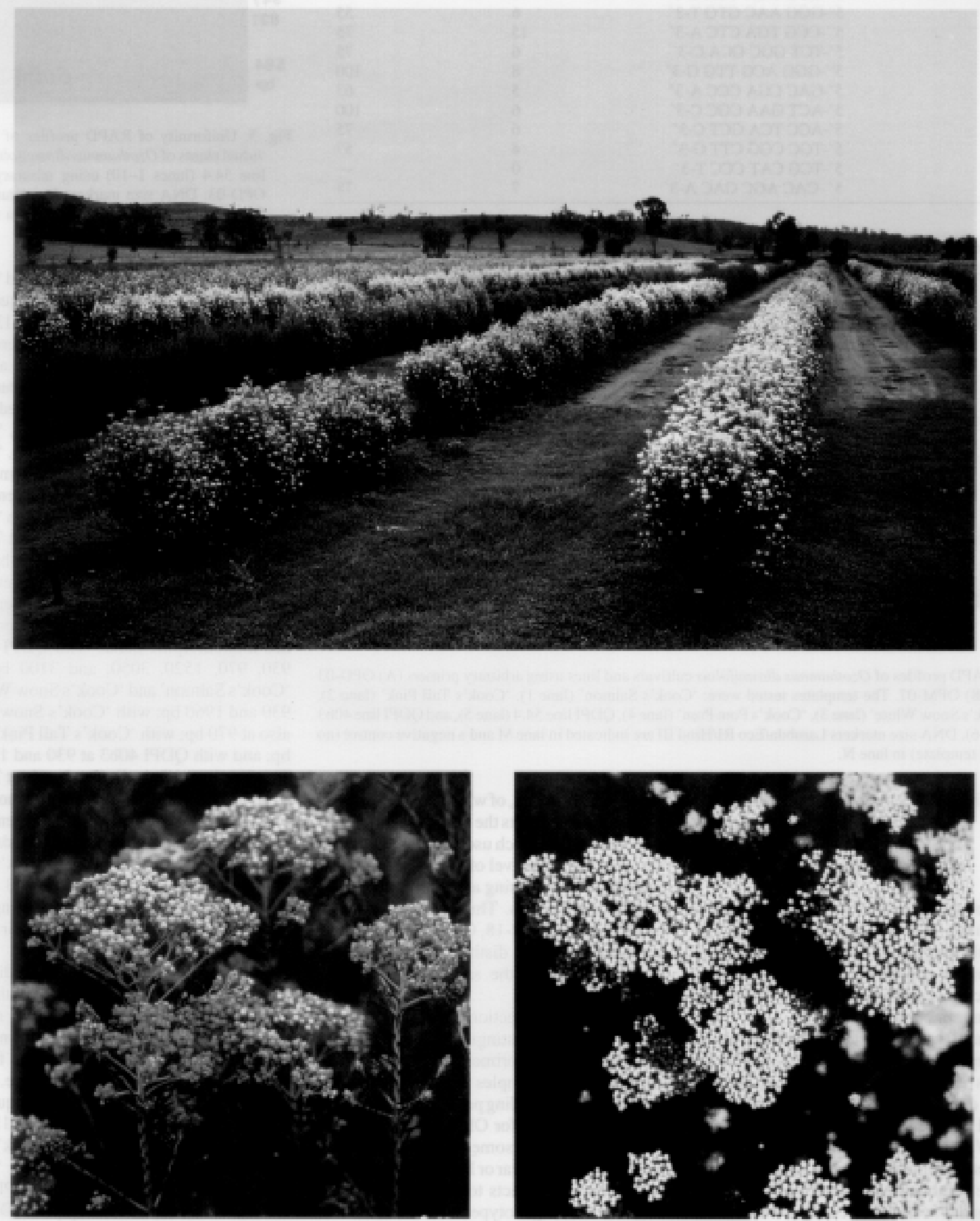

Fig. 1. (top) Flowering Ozothamnus diosmifolius shrubs (to $1.5 \mathrm{~m}$ height) and close-up of corymbs [(bottom left) 'Cook's Salmon' and (bottom right) 'Cook's Snow White')]. 
Table 2. Arbitrary primer sequences used in RAPD-PCR of Ozothamnus diosmifolius.

\begin{tabular}{|c|c|c|c|}
\hline \multirow[b]{2}{*}{ Primer } & \multirow[b]{2}{*}{ Sequence } & \multicolumn{2}{|c|}{ Polymorphic markers } \\
\hline & & No. & Percent \\
\hline$\overline{\mathrm{OPD}-03}$ & $5^{\prime}-\mathrm{GTC}$ GCC GTC A-3' & 14 & 70 \\
\hline OPD-05 & $5^{\prime}-\mathrm{TGA}$ GCG GAC A-3' & 5 & 63 \\
\hline OPD-08 & $5^{\prime}-\mathrm{GTG}$ TGC CCC A-3' & 9 & 82 \\
\hline OPD-11 & $5^{\prime}-\mathrm{AGC}$ GCC ATT G-3' & 5 & 71 \\
\hline OPD-13 & $5^{\prime}-\mathrm{GGG}$ GTG ACG A-3' & 4 & 44 \\
\hline OPD-15 & $5^{\prime}-\mathrm{CAT}$ CCG TGC T-3' & 9 & 56 \\
\hline OPD-18 & $5^{\prime}-\mathrm{GAG}$ AGC CAA C-3' & 0 & --- \\
\hline OPD-20 & $5^{\prime}-\mathrm{ACC}$ CGG TCA C-3' & 6 & 60 \\
\hline OPM-03 & $5^{\prime}-\mathrm{GGG}$ GGA TGA G-3' & 0 & -- \\
\hline OPM-05 & $5^{\prime}-\mathrm{GGG}$ AAC GTG T-3' & 6 & 55 \\
\hline OPM-07 & $5^{\prime \prime}-\mathrm{CCG}$ TGA CTC A-3' & 15 & 75 \\
\hline OPM-10 & $5^{\prime}-\mathrm{TCT}$ GGC GCA C-3' & 6 & 75 \\
\hline OPM-12 & $5^{\prime \prime}-\mathrm{GGG}$ ACG TTG G-3' & 8 & 100 \\
\hline OPN-04 & $5^{\prime}-\mathrm{GAC}$ CGA CCC A-3' & 5 & 63 \\
\hline OPN-05 & $5^{\prime}$-ACT GAA CGC C-3' & 6 & 100 \\
\hline OPN-08 & $5^{\prime}-\mathrm{ACC}$ TCA GCT C-3' & 6 & 75 \\
\hline OPN-09 & $5^{\prime}-\mathrm{TGC}$ CGG CTT G-3' & 4 & 57 \\
\hline OPW-10 & $5^{\prime}-\mathrm{TCG}$ CAT CCC T-3' & 0 & -- \\
\hline OPW-13 & $5^{\prime}-\mathrm{CAC}$ AGC GAC A-3' & 7 & 78 \\
\hline
\end{tabular}

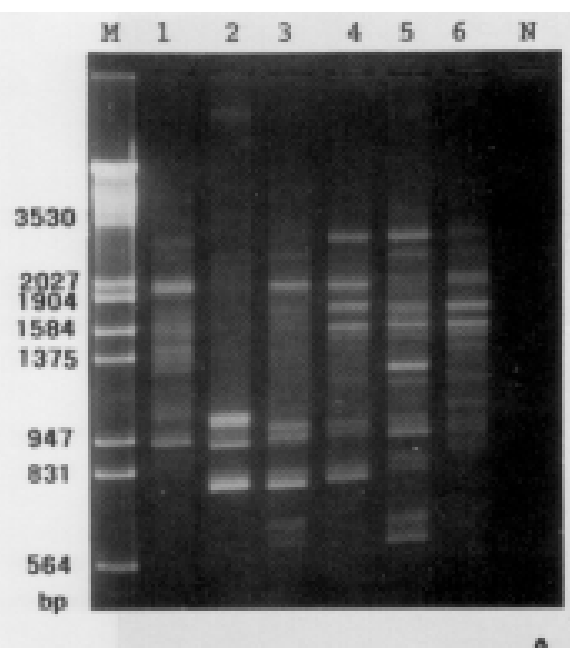

A.

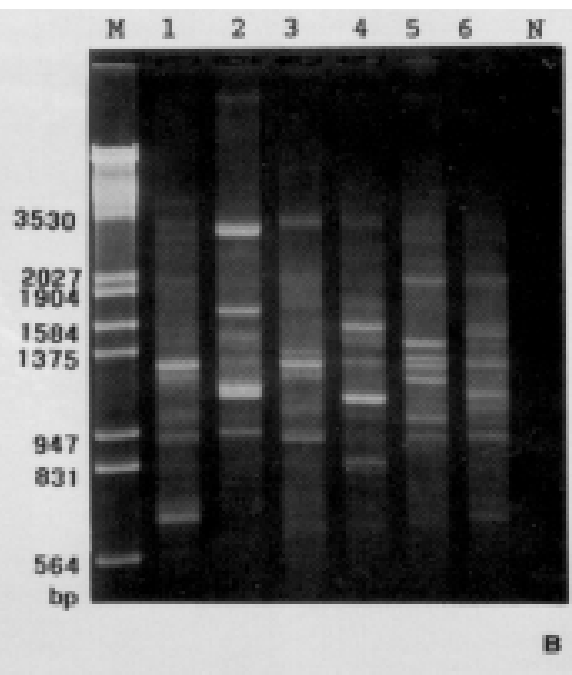

Fig. 2. RAPD profiles of Ozothamnus diosmifolius cultivars and lines using arbitrary primers (A) OPD-03 and (B) OPM-07. The templates tested were: 'Cook's Salmon' (lane 1), 'Cook's Tall Pink' (lane 2), 'Cook's Snow White' (lane 3), 'Cook's Pom Pom' (lane 4), QDPI line 54.4 (lane 5), and QDPI line 40b3 (lane 6). DNA size markers Lambda/Eco RI/Hind III are indicated in lane M and a negative control (no DNA template) in lane $\mathrm{N}$.

distinguished the latter from the other genotypes.

\section{Results and Discussion}

Under the described PCR conditions, the combination of $3 \mathrm{~mm} \mathrm{MgCl}_{2}, 1$ unit of Taq DNA polymerase, and $30 \mathrm{ng}$ of template were the optimum concentrations for reliable and reproducible amplification, and produced the optimum number of markers.

Of the 19 primers tested, 16 (84\%) showed polymorphisms between at least two of the six cultivars and lines, independent of the GC content of the primers. Similar results were reported by Levi et al. (1993), Wolff and Peters-Van Rijn (1993), and Wolff et al. (1993) for other Asteraceae species. Each primertemplate combination yielded 6 to 20 distinct major bands of variable intensities, which could be scored, and many indistinct bands that were produced due to nonspecific amplification and thus ignored. A total of 166 distinct major bands was produced, of which $70 \%$ were polymorphic. Table 2 lists the number of polymorphic markers that each used primer yielded, to illustrate the high level of polymorphism that could be detected using arbitrary primers in a PCR of this species. Three primer-template combinations (OPD-18, OPM-03, and OPW10) did not amplify distinct fragments, making distinction of the samples using these primers impossible.

With careful selection only a few primers were required to distinguish all six cultivars and lines. Several primers were able to discriminate all six samples from one another by yielding unique banding patterns for each genotype, as illustrated for OPD-03 and OPM-07 (Fig. 2). Although some bands were monomorphic, each cultivar or line produced unique amplification products to distinguish it from the other tested genotypes.

Using primer OPD-03, 'Cook's Salmon' has a monomorphic band with all other tested genotypes, except 'Cook's Tall Pink', at 930

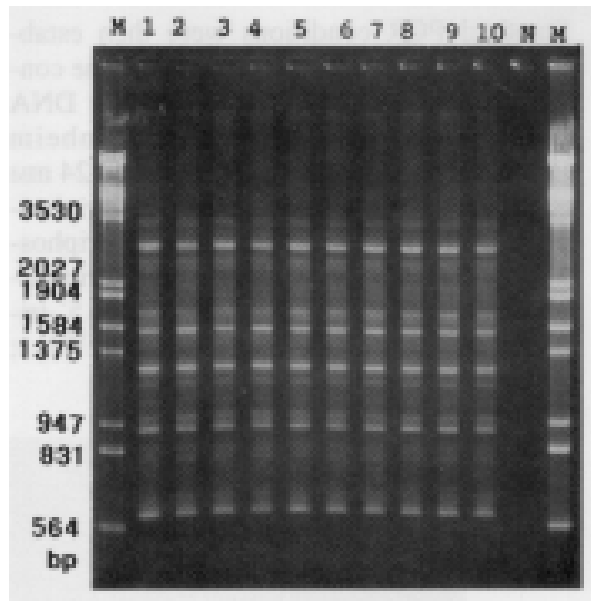

Fig. 3. Uniformity of RAPD profiles of 10 individual plants of Ozothamnus diosmifolius QDPI line 54.4 (lanes 1-10) using arbitrary primer OPD-03. DNA size markers Lambda/Eco RI/ Hind III are shown in lane $\mathrm{M}$ and a negative control in lane $\mathrm{N}$.

bp, and with 'Cook's Snow White' and 'Cook's Pom Pom' at 1960 bp, but has a unique major and distinct polymorphic band at $1390 \mathrm{bp}$. 'Cook's Tall Pink' has unique markers at 920 and $1020 \mathrm{bp}$ to distinguish it from all other tested genotypes. A monomorphic band with 'Cook's Snow White' was amplified at 760 bp, and with 'Cook's Snow White', 'Cook's Pom Pom', and QDPI 54.4 at 970 bp. 'Cook's Snow White' does not have a unique marker to discriminate it from the other five genotypes; however, it can be distinguished from 'Cook's Salmon' by the presence of bands at 760 and $970 \mathrm{bp}$ and the absence of a 1390-bp band, from 'Cook's Tall Pink' by the presence of a 930- and 1960-bp band and the absence of a 920- and 1020-bp band. 'Cook's Pom Pom' has monomorphic bands with QDPI 54.4 at 930, 970, 1520, 3050, and 3100 bp; with 'Cook's Salmon' and 'Cook's Snow White' at 930 and 1960 bp; with 'Cook's Snow White' also at 970 bp; with 'Cook's Tall Pink' at 970 bp; and with QDPI $40 \mathrm{~b} 3$ at 930 and $1520 \mathrm{bp}$. This line has unique distinct bands at 770 and $1780 \mathrm{bp}$. QDPI 54.4 has one to five monomorphic markers with the other five genotypes, but it also amplified two unique bands of 590 (only present very faintly in 'Cook's Snow White') and $1250 \mathrm{bp}$. QDPI $40 \mathrm{~b} 3$ has no unique markers, but it can be distinguished from the other five genotypes by their general amplification profiles.

Similar comparisons of the banding profiles of the genotypes can be made with primer OPM-07. Although monomorphic markers with some of the other cultivars or lines were amplified, the total banding profile for each genotype can be regarded as unique. In particular, 'Cook's Salmon' has a unique polymorphic band at $695 \mathrm{bp}$; 'Cook's Tall Pink' at 990, 1170, 1720, and 2520 bp; 'Cook's Snow White' at 940, 1320, and $1375 \mathrm{bp}$; 'Cook's Pom Pom' at 870 and 1125 bp; QDPI 54.4 at 947, 1200, 1270, and $1350 \mathrm{bp}$; and QDPI 40b3 at 1080,1155 , and $1520 \mathrm{bp}$.

A high level of genetic variability between cultivars and lines was expected due to the 
seedling origin of the original single plant selections and subsequent use of clonal propagation to maintain the identity of each line. Consistent with the knowledge that the material was clonally propagated, PCR amplification profiles did not show intracultivar differences, since all the genetic information of individuals within a clone is theoretically identical, as illustrated with 10 individual plants of QDPI line 54.4 using primer OPD-03 (Fig. 3).

Riceflower is becoming a rapidly expanding and highly profitable commodity in the Australian ornamental industry. The results of this study indicate that RAPD-PCR analysis is a highly useful, simple, and reliable technique for identifying genetic variability in the early stages of growth in this species, provided established reaction conditions are kept under strict control to ensure reproducibility of the results.

The results of this preliminary study with a selected and limited number of cultivars and lines indicate strongly that RAPD may be developed and applied to a larger number of samples and genotypes. Thus, the protocol reported here can be used for routine analysis of identity in $O$. diosmifolius and possibly related species, such as $O$. diotophyllus (F. Muell.) Anderb. and O. obcordatus DC.

\section{Literature Cited}

Beal, P.R. (1994). Evaluation of riceflower (Helichrysum diosmifolium syn. Ozothamnus diosmifolius) selections for cut flower production, p. 13-17. In: Proceedings of third national workshop for Australian wildflowers. Gatton, Queensland, Australia.

Brunel, D. 1994. A microsatellite marker in Helianthus annuus L. Plant Mol. Biol. 24:397400.

Cook, E. and M.A. Law. 1993. Riceflower Helichrysum diosmifolium. Plant Varieties J. 6:43-47.

Fritsch, P., M.A. Hanson, C.D. Spore, P.E. Pack, and L.H. Rieseberg. 1993. Constancy of RAPD primer amplification strength among distantly related taxa of flowering plants. Plant Mol. Biol. Rpt. 11:10-20.

Graham, G.C., P. Mayers, and R.J. Henry. 1994. A simplified method for the preparation of fungal genomic DNA for PCR and RAPD analysis. BioTechniques 16:48-50.

Lawson, W.R., R.J. Henry, J.K. Kochman, and G.A.
Kong. 1994. Genetic diversity in sunflower (Helianthus annuus L.) as revealed by random amplified polymorphic DNA analysis. Austral. J. Agr. Res. 45:1319-1327.

Levi, A., L.J. Rowland, and J.S. Hartung. 1993. Production of reliable randomly amplified polymorphic DNA (RAPD) markers from DNA of woody plants. HortScience 28:1188-1190.

Rieseberg, L.H., H. Choi, R. Chan, and C. Spore. 1993. Genomic map of a diploid hybrid species. Heredity 70:285-293.

Saiki, R.K., D.H. Gelfand, S. Stoffel, S.J. Scharf, R. Higuchi, G.T. Horn, K.B. Mullis, and H.A Erlich. 1988. Primer-directed enzymatic amplification of DNA with a thermostable DNA polymerase. Science 239:487-491.

Williams, J.G.K., A.R. Kubelik, K.J. Livak, J.A. Rafalski, and S.V. Tingey. 1990. DNA polymorphisms amplified by arbitrary primers are useful as genetic markers. Nucleic Acids Res. 18:6531-6535.

Wolff, K. and J. Peters-Van Rijn. 1993. Rapid detection of genetic variability in chrysanthemum (Dendranthema grandiflora Tzvelev) using random primers. Heredity 71:335-341.

Wolff, K., E.D. Schoen, and J. Peters-Van Rijn. 1993. Optimizing the generation of random amplified polymorphic DNAs in chrysanthemum. Theor. Appl. Genet. 86:1033-1037. 